$$
\begin{gathered}
5534 \\
16 A 5 \\
1922
\end{gathered}
$$



Department of Agricultural Extension of Purdue University, Federal Board for Vocational Education, and U.S. Department of Agriculture, Co-operating

\section{Club and Vocational Training in Farming and Home-making in Fountain County}

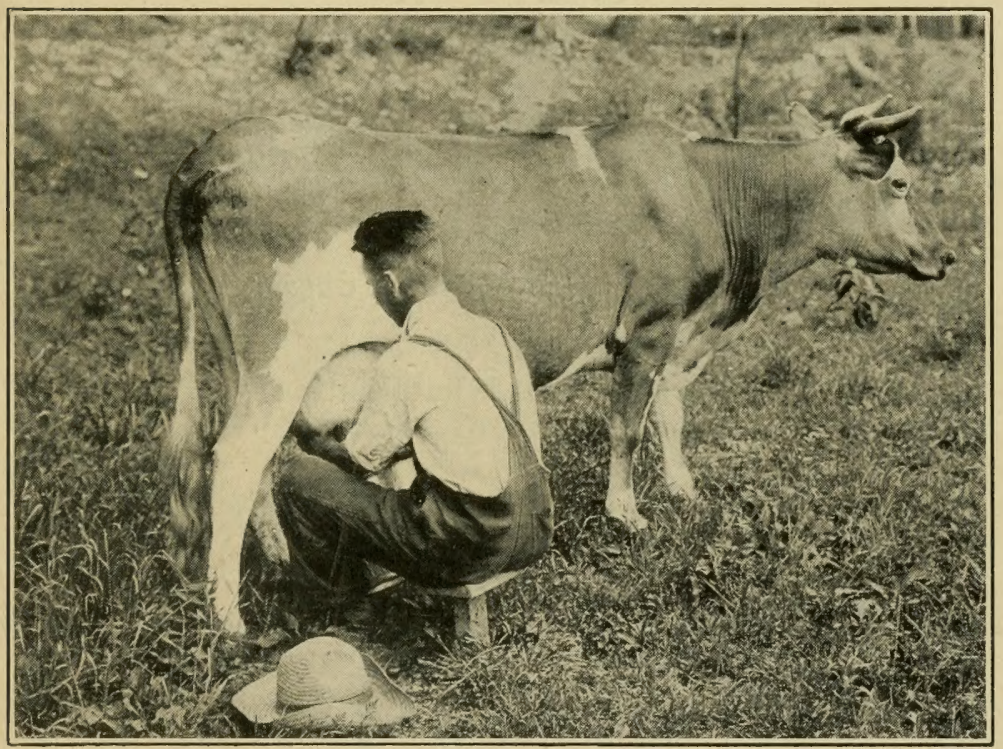

Edward Mallett graduated from high school in the Vocational Agriculture course in 1921. He was a club member for six years. He is now developing a purebred Guernsey herd. This cow is the foundation animal of his herd.

Prepared under the direction of Benjamin J. Burris

State Superintendent of Public Instruction

By

Z. M. Smith

State Supervisor of Agricultural Education

April, 1922

Wm, B. Burford, Indianapolis. 
State of Indiana

DEPARTMENT OF PUBLIC INSTRUCTION INDIANAPOLIS

Benjamin J. Burris, Superintendent

Division of Vocational Education

E. A. Wreidt, Director

Z. M. SMITH

Supervisor of Agricultural Education

BERTHA LATTA

Supervisor of Home Economics Education

H. G. McCOMB

Supervisor of Industrial Education

L. B. JOB

Supervisor of Rehabilitation

LIBRARY OF CONGRESO

DEC:EIVED

FEB 231932

DIVISION OF DOCUREETS 


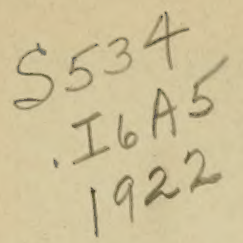

It is with pleasure that I officially and personally endorse club work and vocational instruction when conducted in the manner described in this bulletin. The facts herein set out show clearly the desirability and the value of co-operation of all agencies in a community in formulating and carrying out through the public schools a program of education that conforms to rural needs.

The principles expressed and implied in this bulletin should be applied consistently in every community in Indiana.

BENJAMIN J. BURRIS,

State Superintendent of Public Instruction. 


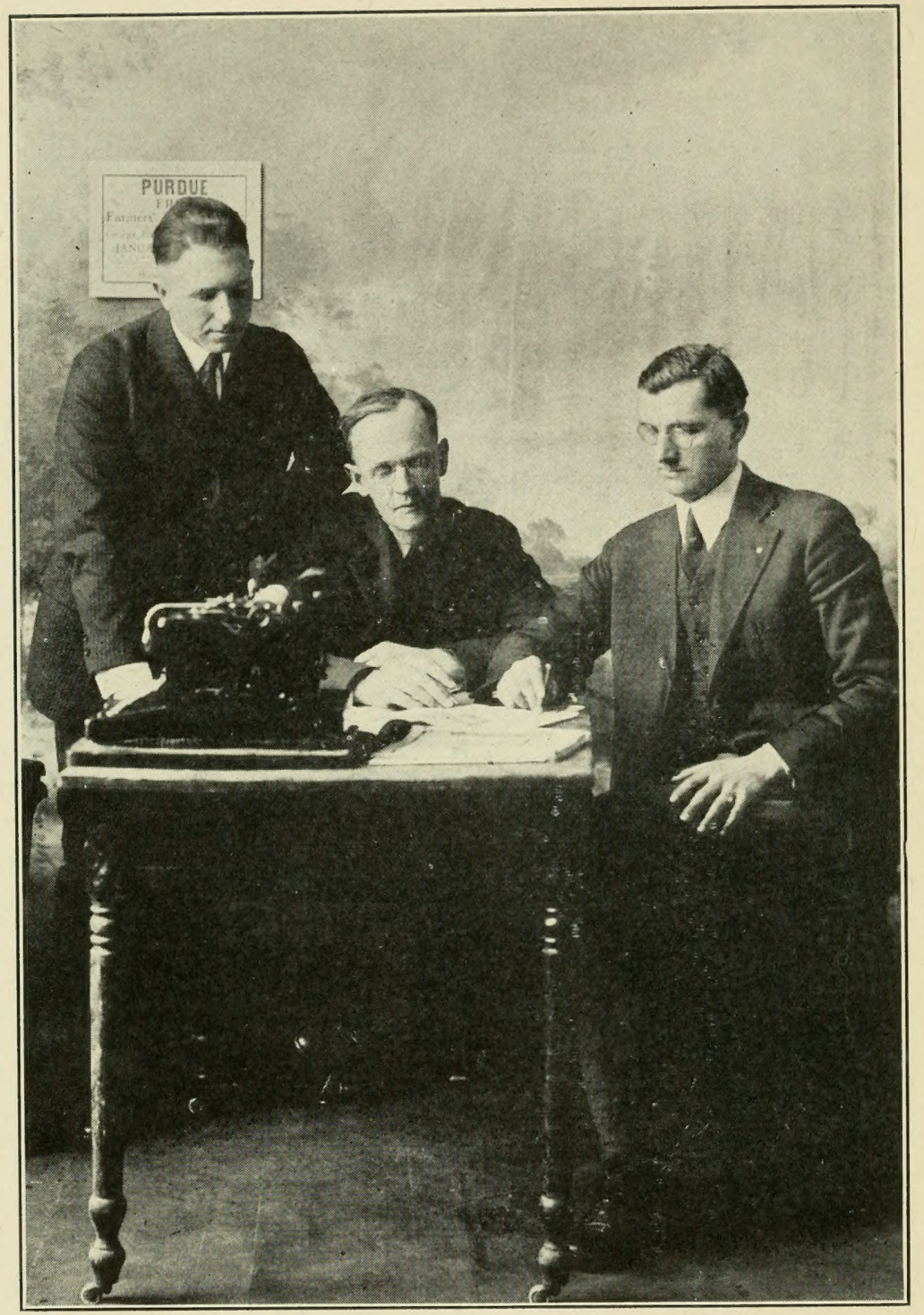

Club and vocational work commands and receives the best thought of these three leaders. A. J. Hesler
County Club Leader R. H. Silverthorn County Agent

Guy A. Waldrip

County Superintendent of Schools 


\section{Club and Vocational Training in Farming and Home- making in Fountain County}

This bulletin is a brief story of how Fountain County, Indiana, is correlating farm, home and school in a manner that is improving farm practice and home-making and is making the school interesting to the children.

\section{County Organization}

The program is organized on a basis to avoid duplication of workers and expenditure of funds, and to prevent the possibility of working at cross-purposes. Organizations of countywide scope are co-operating with unanimity in effecting a realization of the aims of those who officially bear the responsibility of leadership. Among these county agencies are the county superintendent of schools and board of education, the county agricultural agent, the county club leader, the county fair board, the county farm bureau, the county commissioners, the county council, the county bankers' association, the county livestock breeders associations. These county organizations are assisted by state and federal agents representing the agricultural extension department of Purdue University, the state department of public instruction, the federal board for vocational education, and the United States Department of Agriculture.

The program is constructed on the farm, the home and the school problems of the county. The county needs more and better beef cattle, dairy cattle, hogs, poultry, sheep, corn, apples, potatoes, legumes. With the improvement in livestock and crops is expected modern homes, consolidated schools with high grade teachers and adequate equipment, improved roads, churches suitable to rural needs, and a satisfying social life.

How are the boys and girìs contributing to the successful execution of this program? Their school work in agriculture and home economics is outlined on a project basis by the county superintendent of schools, the county agricultural agent, the county club leader and representatives of the state and federal offices in charge of extension and vocational work. 
For example, the projects for agriculture in the schools this year (1921-1922) are hogs, poultry and potatoes. These are the phases of agriculture that the farm bureau and county agent think should be emphasized in the adult county program. Next year the projects will deal with beef and dairy cattle, sheep and corn. The subject matter for each project is arranged in seasonal sequence, so that each month the reference readings, class discussions, laboratory and field work, apply directly to the normal progress of the project as a regular farm enterprise. For example, poultry culling is studied and the culling is done in the fall of the year; poultry housing, feeding and management are studied and practiced during the fall, winter and spring months; poultry breeding, hatching, brooding, and chick raising are studied and carried out in practice during the spring and summer. This work is made an integral part of the county program for securing more and better poultry. In like manner the principle applies to all phases of the county program.

The practical work in connection with each project is organized and carried out on a junior extension or club basis. Each boy and girl keeps records and notes on cost and income items, on problems connected with seed selecting and testing, soil management, prevention and control of diseases and pests, canning, garment making, etc., and upon completion of the project submits his or her record, written account, and sample of product in competition with similar exhibits at the annual county fair.

The county fair board, the banks, the farm bureau, and commercial concerns, encourage the boys and girls by providing premiums for the club contests. The county commissioners and the township trustees supply the funds for expenditures in connection with supervision of the club and vocational projects. The vocational teachers supervise the projects of pupils in the elementary grades in addition to the projects of their high school vocational pupils. In short, all agencies in the county are working together on the county program.

\section{Township Organization}

Co-operating with the county leaders and agencies, there is in each township a leader and a committee. These local leaders and committees personally supervise the project work of the boys and girls and co-operate with the schools in carrying 

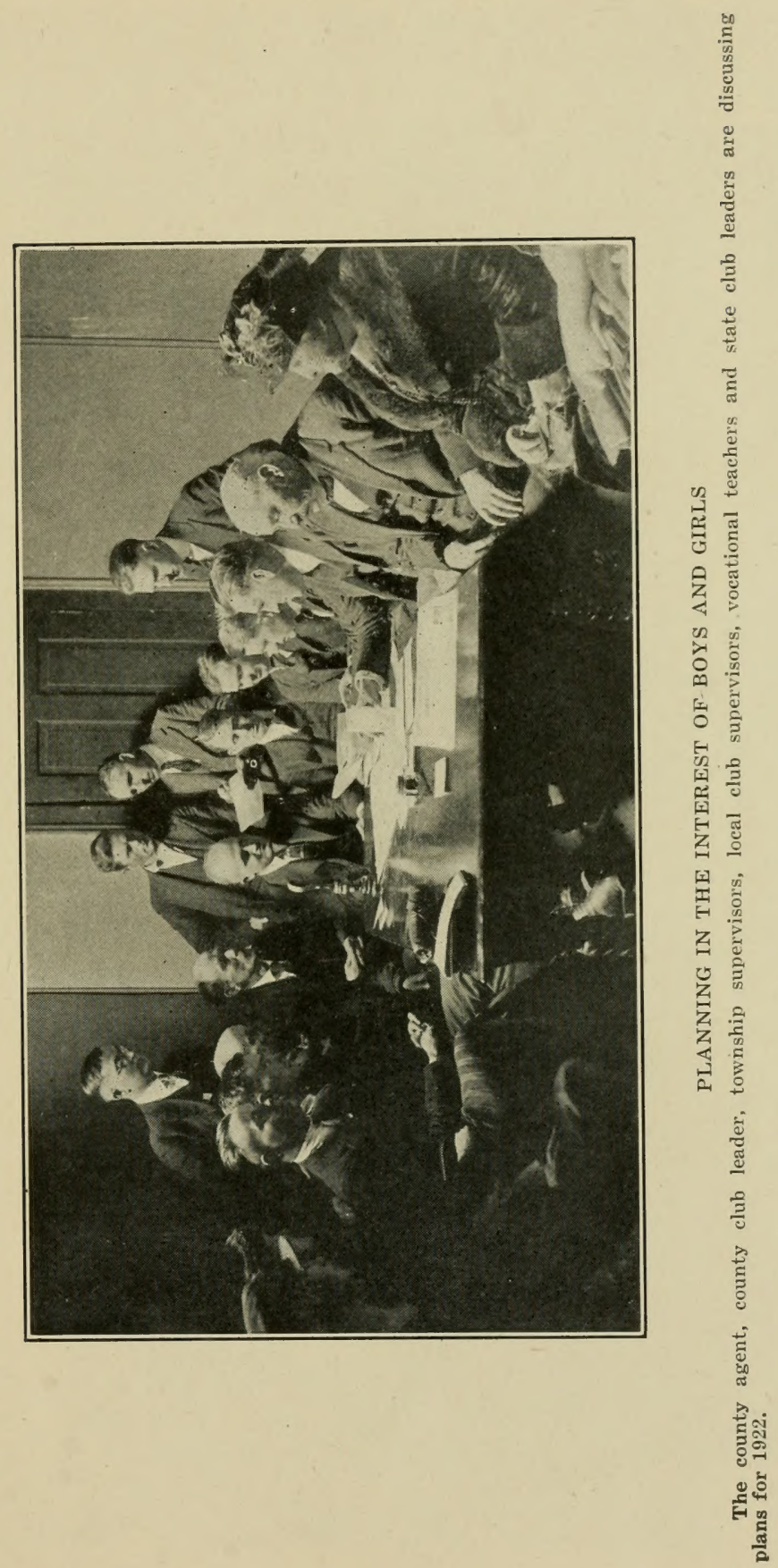


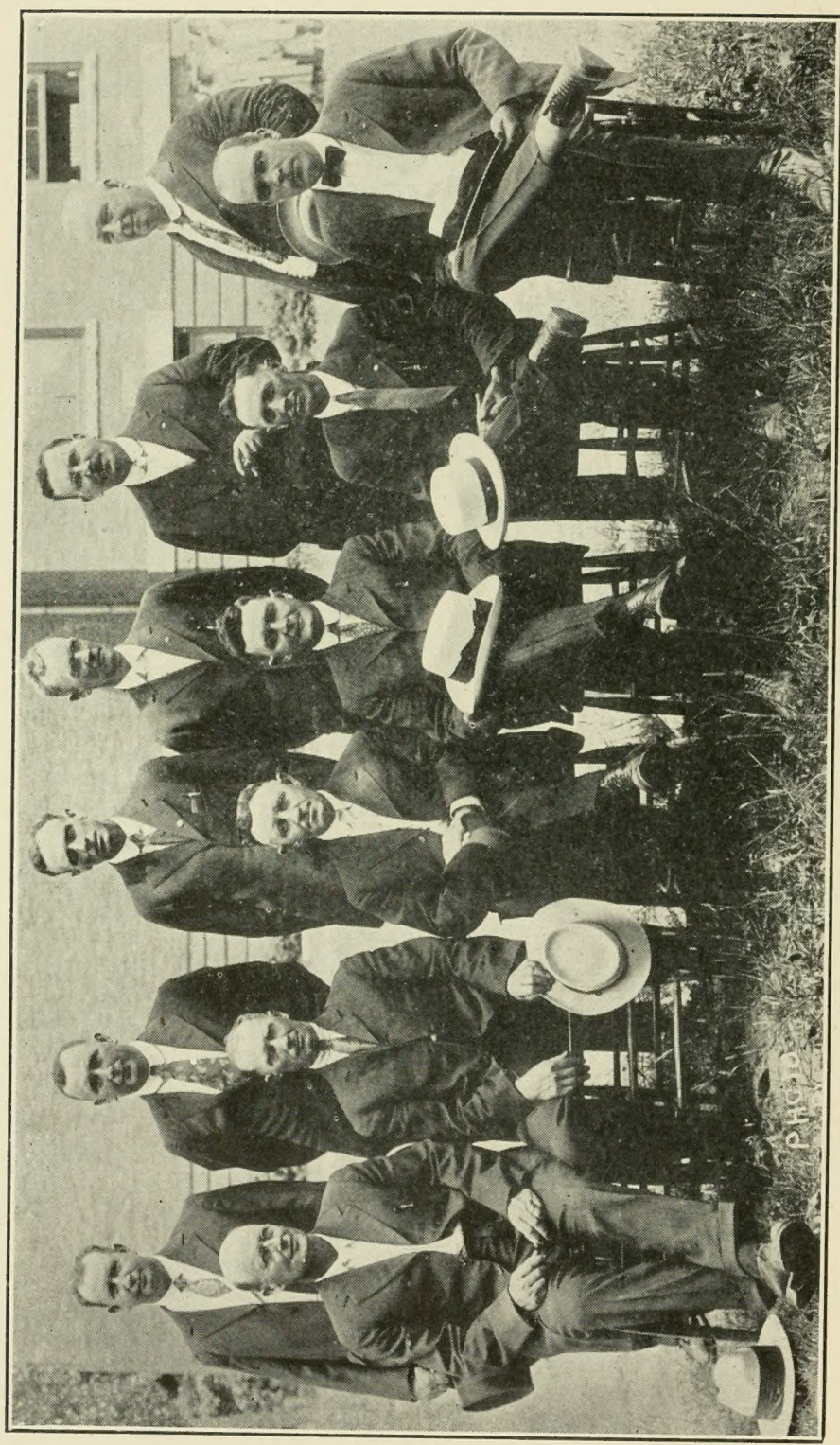

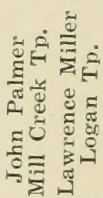

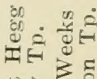

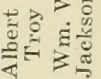

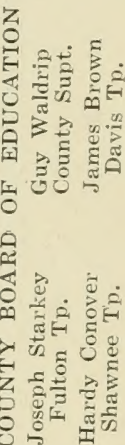

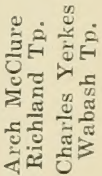

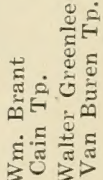




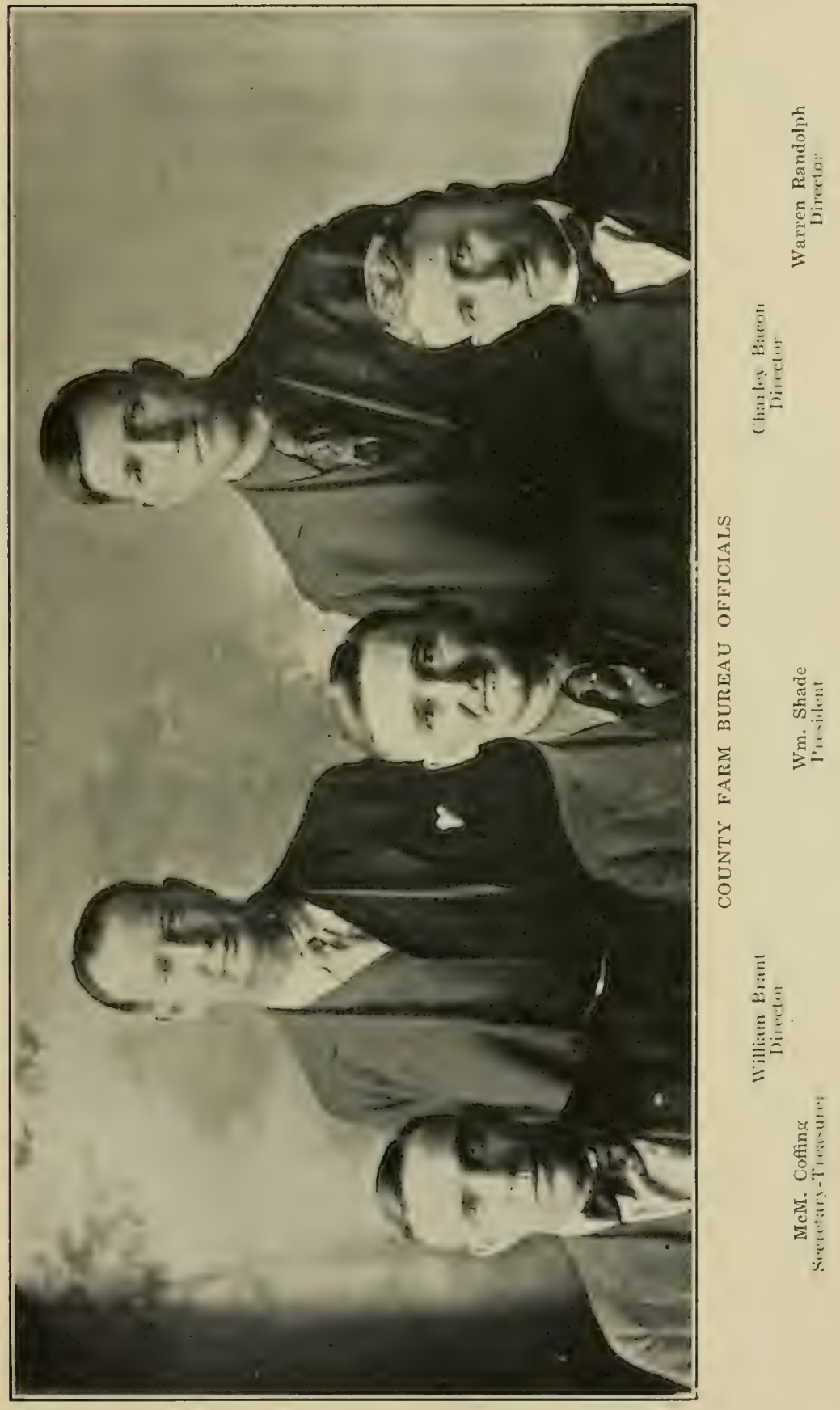


out the plan of providing the necessary instruction in subject matter relating to the projects. Without the close personal touch of local leader's and supervisor's, the boys and girls fail to measure up to their greatest possibility in achievement. The township club contests, exhibits, short courses, achievement day programs, and school instruction are fundamentally requisite to a successful prosecution of the county program.

\section{Results Accomplished}

Leadership. One of the outstanding and far-reaching results accomplished is the discovery and development of leader's. Space will not permit the mention in detail of all of these leader's. Naturally one's attention is turned to the county superintendent of schools. The present incumbent of that office, Mr. Guy A. Waldrip, and his county board of education have been consistent and loyal supporter's of the county program of club and vocational work. Mr. Waldrip says, "We have evolved a system that vitalizes the teaching of agriculture and home cconomics. Through the club work the child does things, and makes practical application of school instruction. We regard the club work as a part of seventh and eighth grade agriculture and home economics, and to omit it would be a step backward in our scheme of education. This county is essentially agricultural and the club work rounds out the outline of the study that would certainly be incomplete without it."

The office of the county agricultural agent, occupied by three different agents since Fountain County inaugurated her program, has filled commendably a strategic position in relation to the promotion of the club and vocational work. The present incumbent of the county agent office, Mr. Richard Silverthorn, is rendering invaluable service to the club and vocational program.

The county club leader, Mr. A. J. Hesler, who has been identified with the county program from its inception, is given a very large share of the credit for the success of the work. As a teacher of agriculture in the Veedersburg high school from 1911 to 1915 and as county club leader since 1915, he has labored tirelessly and effectively for the promotion of the vocational and club program. Mr. William Madigan, a farmer and banker in the county, has been from the beginning of the work a valued advisor of the county and local leader's and has carried his share of the responsibility as an active participant. 

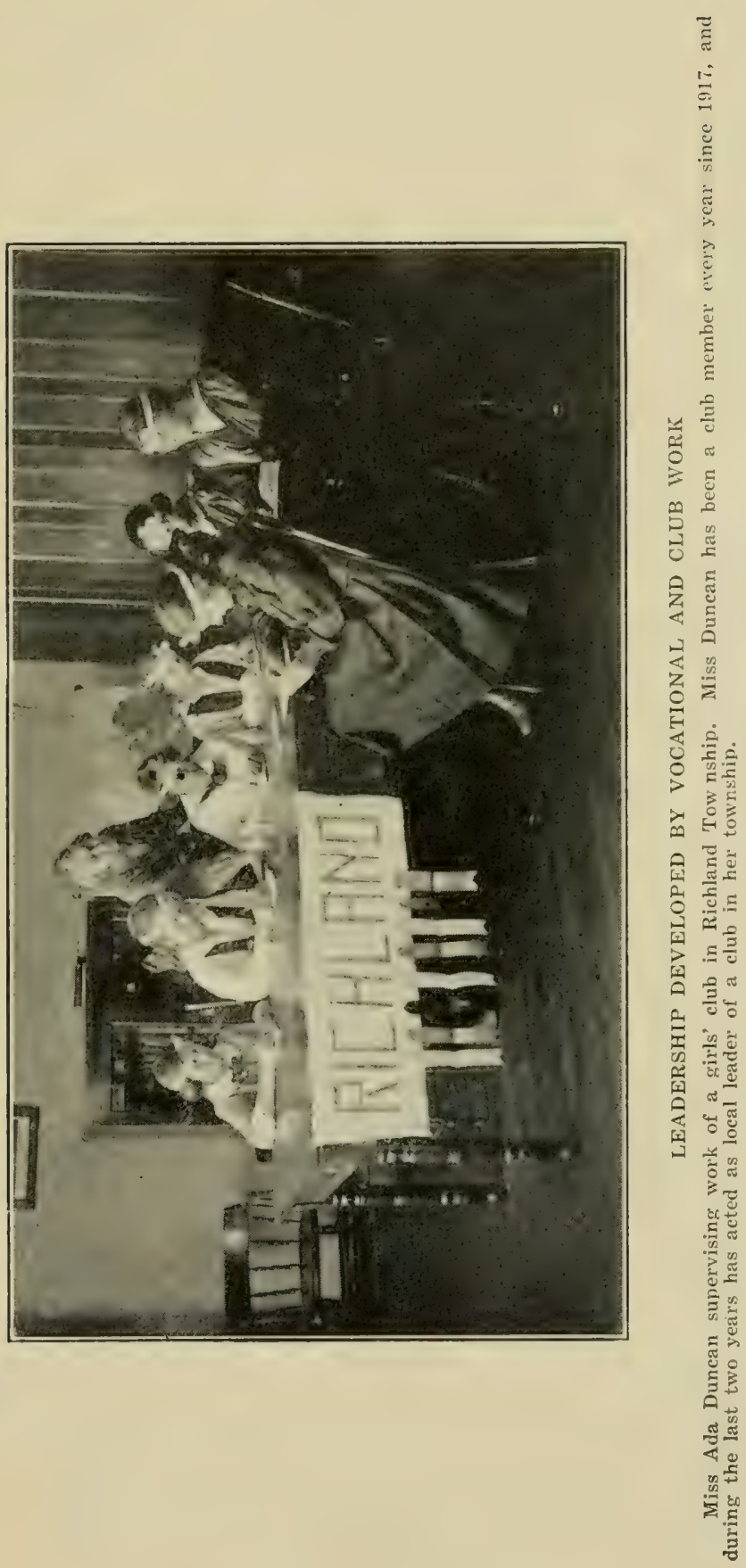
Extended comment could be made consistently concerning the excellent work done by other leaders, including Mr. Lewis Ker'r, Mr. Dan Carpenter, Mr. W. E. Brant, Mr. John Wilson, and a score of other's without whom the present degree of success would not have been realized. Nor must we forget the club member's who have developed into leader's of club groups and without whose aid a program of the present scope would be impossible. Development of leader's is one of the outstanding results accomplished through the vocational and club project work in sewing, baking, canning, and home making.

Ada Duncan has done club work in canning, sewing, baking for the past four years. After her first year she assisted in enrolling member's and promoting the club interest. After she had had three year's experience, she became a local leader and now has taken up leadership for the whole township in girls' club work. September, 1921, she was an outstanding successful exhibitor in the canning contest at the state fair.

Edward Mallett graduated from high school in the vocational agriculture course in 1921. He served in the army one year. He was a pig club member 1915, '16, '17, '18. In 1920 he completed projects in the sow and litter' and corn clubs. He was a calf club member in 1918 and has started to develop a Guernsey herd. Has now a cow and calf. He made his expenses last year in high school selling milk. His dairy interest has given him a position with Purdue University where he is now doing advance registry work. He is one of the oldest and most consistent club members in the county.

Carl Songel will graduate from high school in June, 1922. He has had three year's' vocational work. He expects to enter Purdue Tniversity School of Agriculture in September, 1922. He was state winner in the pig feeding club in 1916. At that time he introduced the self-feeder in his township and his success was responsible for' a large number of self-feeder's among the farmers. Practically every farm in his township now has a self-feeder. He continued his pig club work and was a consistent winner from 1916 until 1920. In 1921 he fed two beef calves. He has been a potato club winner and has demonstrated the value of planting whole potatoes as against small pieces of one and two eyes.

Glen Reed is now a sophomore in the vocational class in high school. He received a pig from the Veedersburg State Bank in 1918 and has been a prize winner for two years. He 
is especially interested in poultry and horticulture. He has managed the home flock of poultry on a profitable basis. $\mathrm{He}$ has had charge of the home orchard for three years. Last summer he made a good profit in strawberries. He is making a substantial enlargement of his small fruit project this year.

Swine Production. Pig feeding projects have been conducted and have increased in number from year to year. Two carloads of the prize animals in the feeding project are exhibited each year at the county fair. A Fountain County club member, Miss Frances Ray, exhibited the championship pen

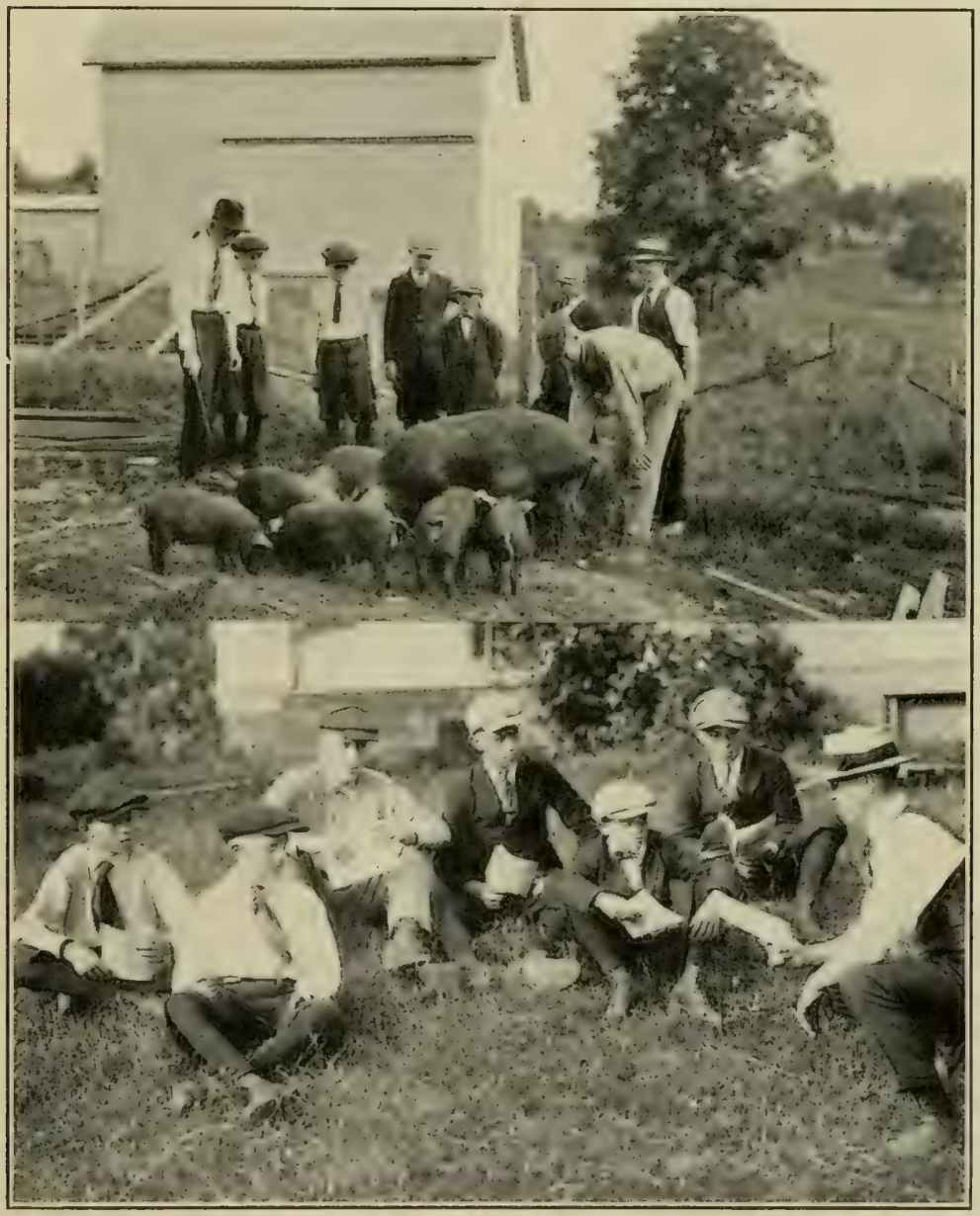

Vocational and club boys visit each other's projects under the supervision of the vocational teacher and then get together to discuss their swine project problems. 


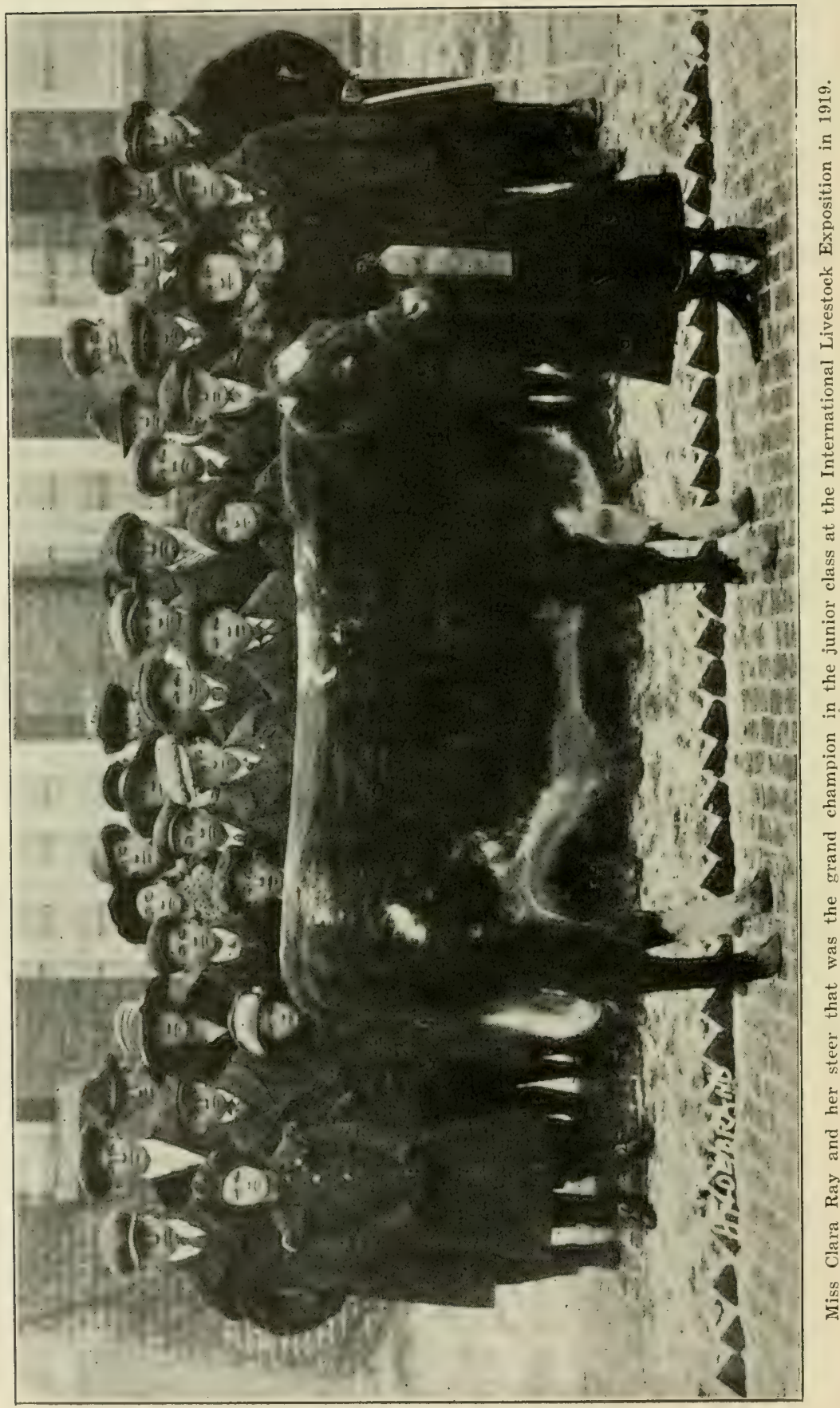




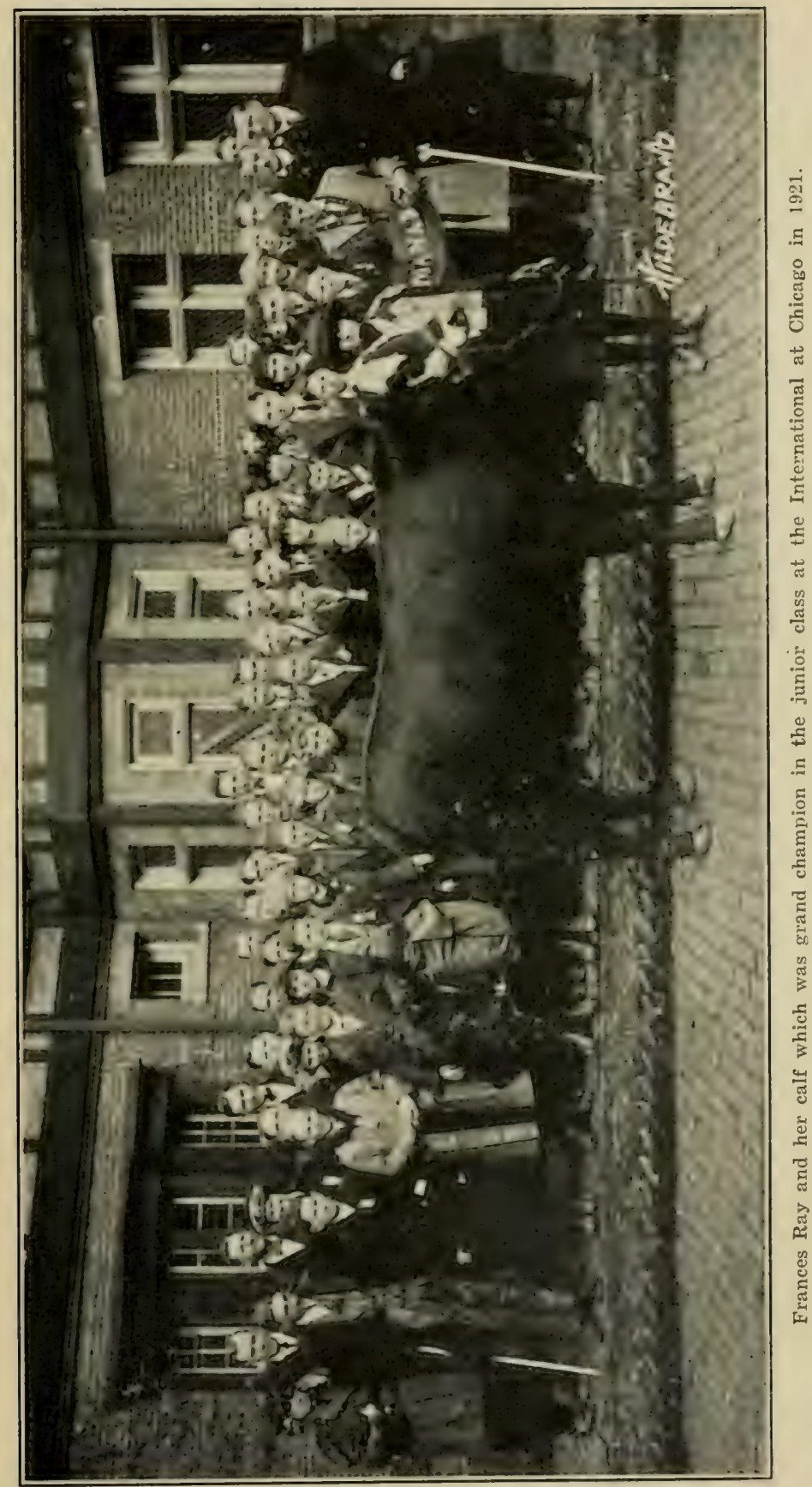


of fat barrows at the International Livestock Exposition at Chicago in 1921.

Sow and litter contests have developed out of the feeding work. The Farmer's' State Bank at Veedersburg has supported loyally both the feeding and the sow and litter projects. The bank at Kingman has financed the sow and litter club in the Kingman community. As a result of the club and vocational work, Fountain County has increased her swine production and has improved greatly the quality of her hogs.

"Pure-bred hogs are expected to be found on every good farm in Fountain County. There was a time when this was not true, and pure-bred hogs were regarded as a fancy of the well-to-do farmer. Pig club work has proven to the average farmer that pure-bred hogs pay. I have noted that every grand champion of the Fountain County pig club exhibit at Covington has been won by a pure-bred. Thousands of people have seen this show each year and it has had a great influence upon making Fountain County approach one hundred per cent work in pure-bred hogs.

Five years ago, when club and vocational work was started in our county, there were no more than five outstanding breeder's of pure-bred hogs in the county to supply the needs. Today there are more than a score of breeders endeavoring to meet the demands of the farmer trade in pure-bred swine. We have not only increased the number of men raising purebreds but have greatly improved the quality and almost doubled the quantity of pork production."

\section{J. S. REED,}

Breeder of Big Type Poland China Hogs,

Veedersburg.

Beef Cattle. Club members from Fountain County have fed and exhibited two of the champion steer's shown in the junior class at the International Livestock Exposition. Miss Clara Ray exhibited the champion steer in the junior class in 1919, and Miss Frances Ray in 1921. Mr.W. W. Layton, president of the First National Bank at Covington says, "The boys' and girls' vocational and club work with calf and pig projects has been the means of developing livestock throughout the county to a high quality in a much quicker way than could have been successfully accomplished by any other method. The good the vocational and club work has accom. 
plished in the way of educating our rising generation can never be measured in dollars and cents. This line of work alone has more than paid for any outlay our county has made for maintaining our county agent office."

"I have always been a lover of good livestock. Men start into the beef cattle business often times with good stock. Yet more failures than successes are a result because of the lack of intelligent feeding and handling.

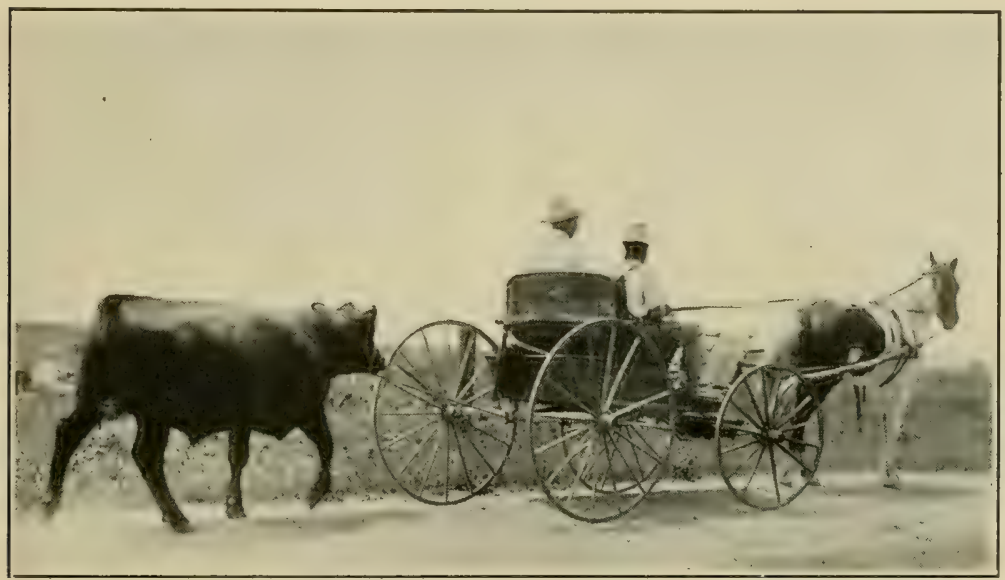

Encil Marlatt and his club leader taking the Angus to a neighboring farm to be weighed. This was a regular monthly trip. This calf won second prize in the junior class at the International Livestock Exposition at Chicago in 1920.

Practically every township in Fountain County has been represented at some time in the baby beef club contest. Over two hundred youngsters have been instructed and can produce the goods. As a result of club and vocational work there is more and better livestock on Fountain County farms than five year's ago. Boys' and girls' baby beef feeding work has been a great incentive for better beef cattle. If the standard is to be maintained we expect the young folks to do it. They know how."

DAN C. REED, Attica.

Dairy Husbandry. "Through the vocational and club projects pure-bred dairy cattle have been brought into the county and farm herds developed from this foundation stock. An importation of Guernsey heifers into the county was made three years ago and from this beginning there has been a substantial development of the dairy business. 
Fountain County in years passed has not been regarded as a dairy county, but conditions are rapidly changing in regard to this industry. Some fundamentals prior to the undertaking of dairying is being advanced by the club people. Within the last five year's the number of pure-bred dairy cattle has doubled and a pure-bred dairy sire is now used. The testing of dairy cattle for tuberculosis has also come within the last five year's. The first work of this kind was done by the vocational class at Veedersburg three years ago. At present we have 75 men signed up for tuberculosis test with 500 cows. These men are lending a helping hand by using their herds to improve the health of Fountain County. We plan to boost

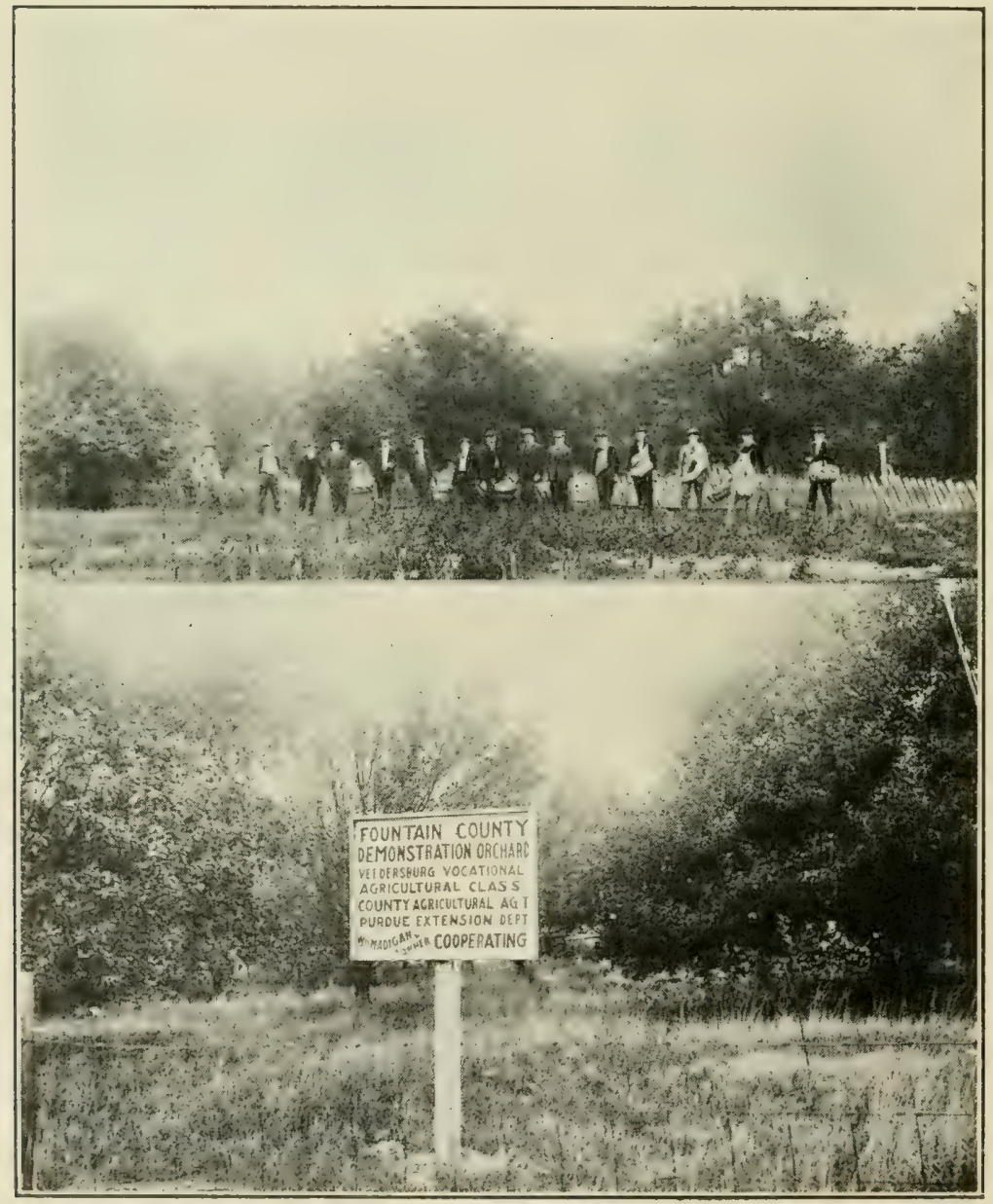


more dairying in Fountain County through the boys' and girls' club work."

\section{J. V. McKNight, Veedersburg.}

\section{Orcharding.}

"Orcharding in Fountain County is profitable. At least one-half of our acreage is adaptable to fruit growing and particularly is there a need on every farm for a home orchard. The old home orchards have about all died out but could be rejuvenated if taken in time. Since club work and rocational

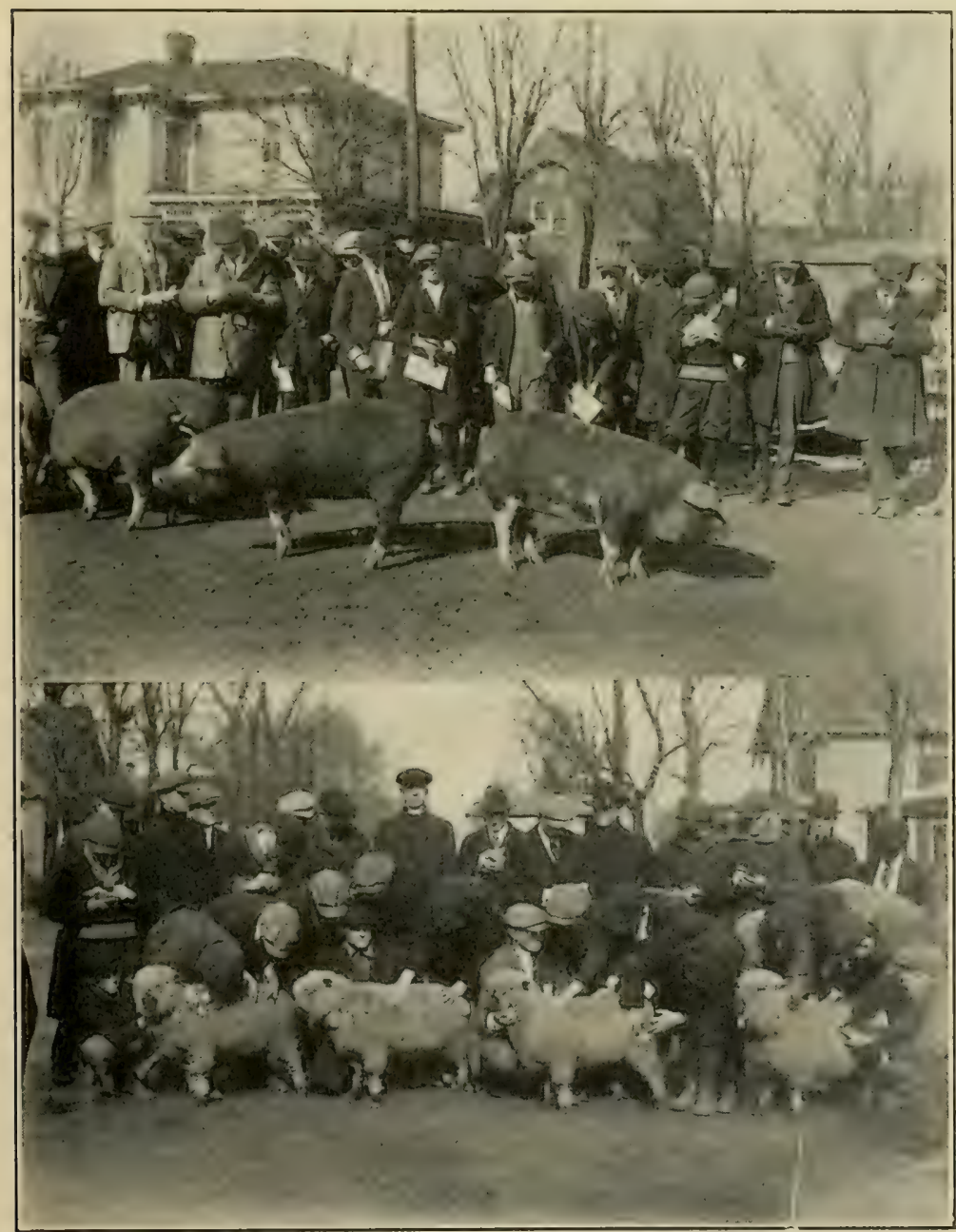

Fountain County club and vocational livestock judging at the anr. al county contest. 
agriculture have been introduced into our rural schools a great stride has been made along this line. Eighty per cent of all old orchards now being treated are being looked after by boys in orcharding projects in the various localities of the county. As commercial growers we hear a lot about the demonstration orchards conducted by vocational boys, and we are sure that new orchards planted and old ones renewed will be done in a large measure by the young people in vocational and club work."

\section{COFFING BROTHERS,}

Silverwood.

\section{Corn Production.}

"The Palin ear of corn a few years ago advertised Fountain County far" and wide as a "Corn King" County. When the opportunity came I moved to Fountain County to raise corn. I found that Fountain County would produce fine corn, and $I$ also found that the schools and club leaders in Fountain County were boosting better corn. As a producer of seed corn I am unable to supply the demand in our own county. The boy has proven to the parent and to the community that better seed increases the yield. Fountain County has a reputation for good corn. Boys' and girls' corn club work has helped to increase the quality of our corn by the disease free seed and ear to the row work. Thru club and vocational work the reputation of Fountain County as a corn county will be maintained."

W. J. ULREY,

Hillsboro.

\section{Household Management.}

"There were one thousand girls' exhibits at the county fair in 1921, consisting of baking and canning club products from every section of the county. It has been interesting to me in my supervision of exhibits to note the quality of work done by these girls. In many instances the girls have excelled the women's department. The friendiy rivalry, the mingling of the contestants, fixing ideals for better homes in Fountain County was evident to the interested onlooker's. Club and vocational work among the girls has been a real contribution to better rural life, better health, comfort and happiness for our people."

Mrs. George Williams, Secretary Women's Division at County Fair. 


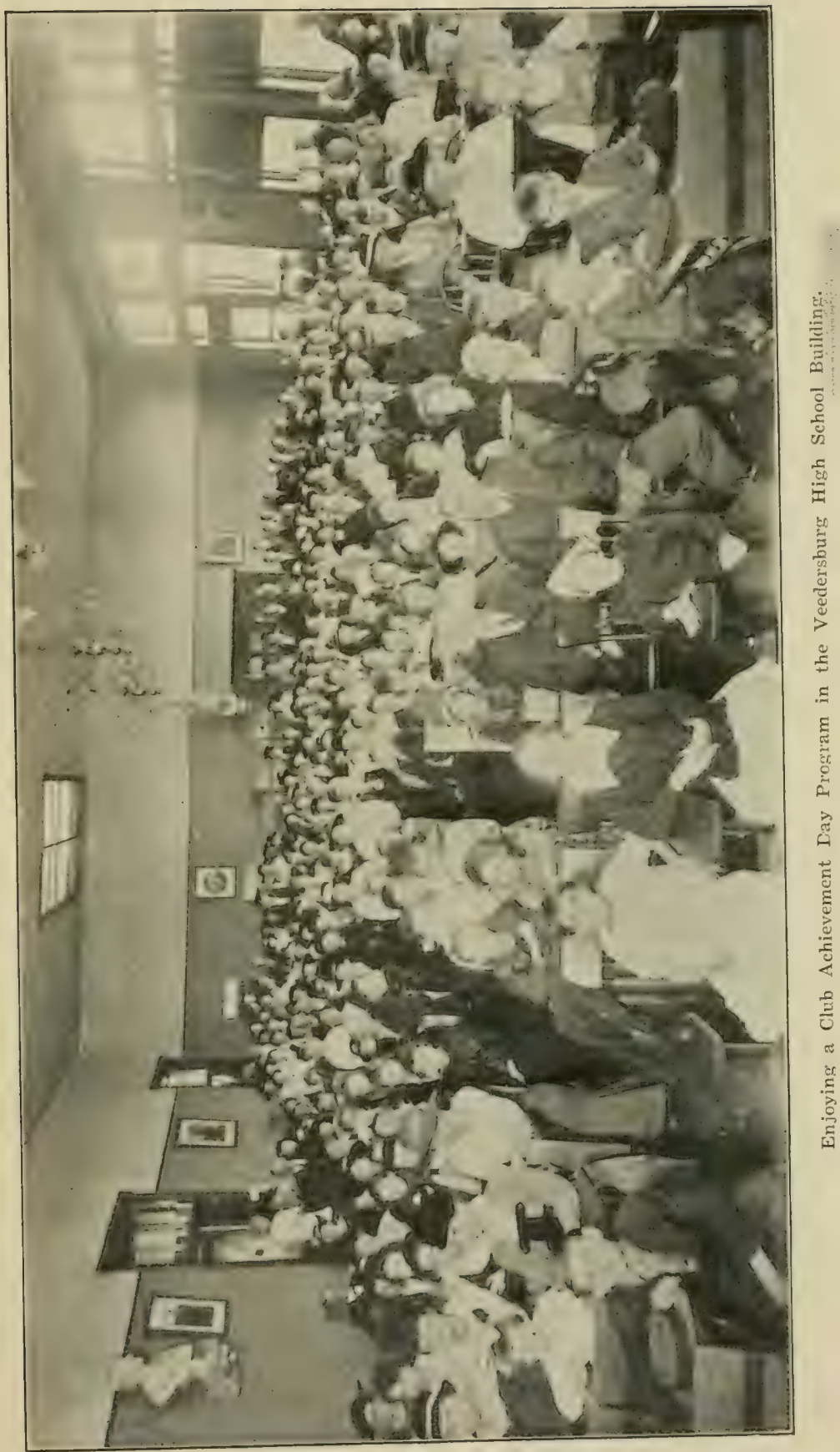




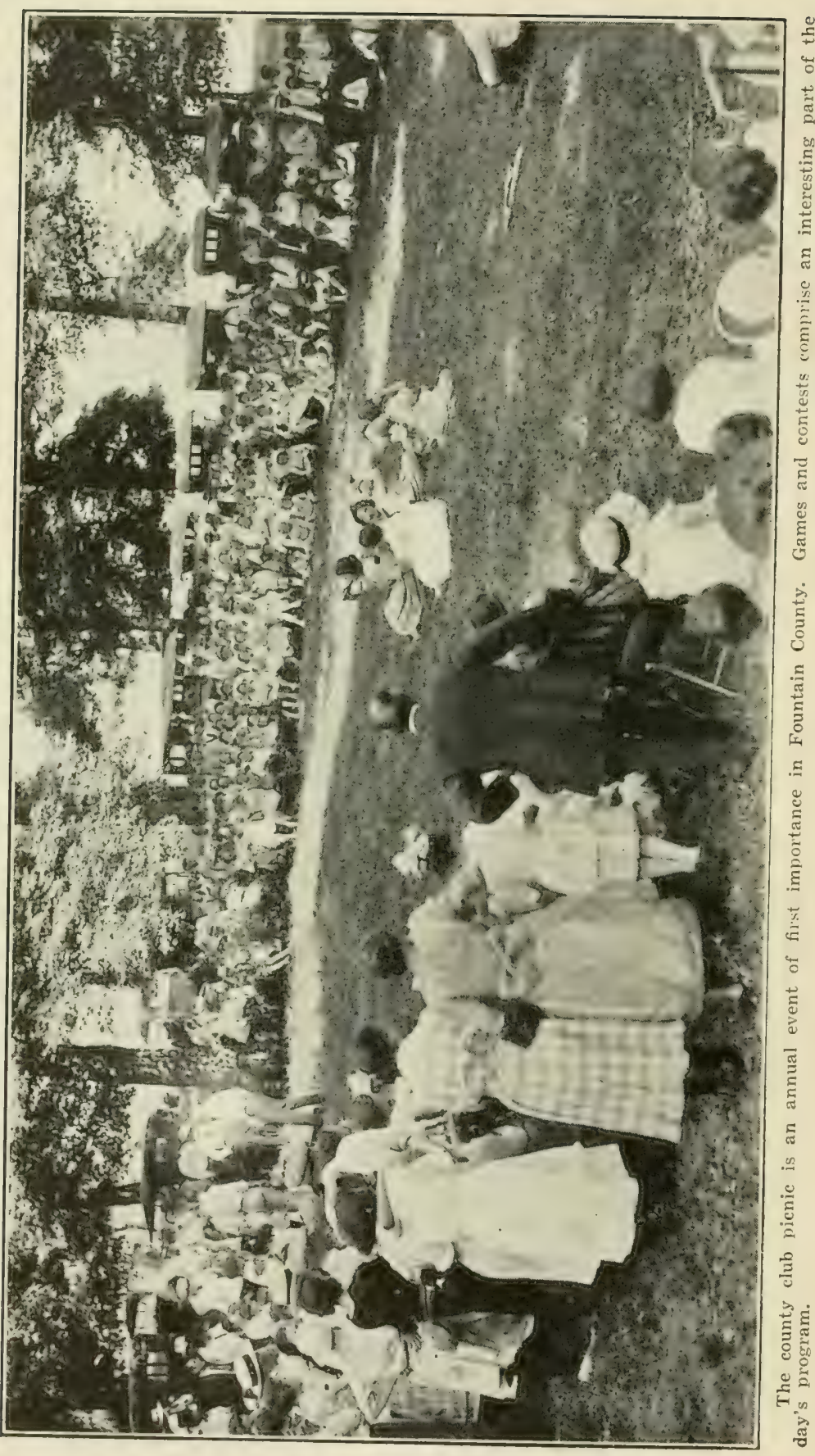




\section{Community Development.}

"Boys' and girls' club work in Fountain County is primarily constructive. For example, in Cain Township there were a few young people in club work. The County Leader visited the trustee who was a firm believer in club work but felt that he did not have a local leader. A teacher was secured as leader and by the end of the second year club work was flourishing. As a result there came a strong demand for vocational agriculture and home economics to be taught. The township had a consolidated school but the building was not adequate. There was no place large enough for community meetings. The boys were forced to travel six miles to play basketball. The community was not united. As a result of one year's work in vocational agriculture, the support of the community was strong enough to enable the trustee to construct a $\$ 100,000$ addition to the school building. In addition to rooms for vocational work, the new building contains a large gymnasium, an auditorium with seating capacity for 1,000 people and one of the most attractive stages seen anywhere. The building is in almost constant use, which discloses the fact that this community has had an awakening and is taking her place among the foremost townships.

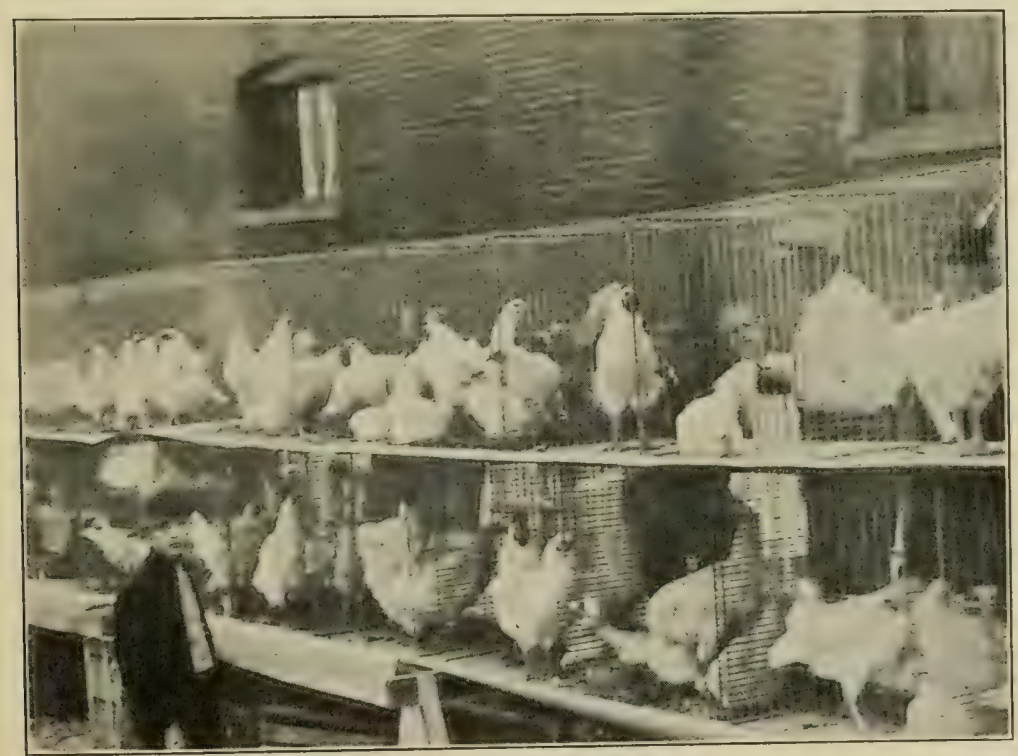

Poultry Exhibit at the Van Buren Township Vocational and Club Achievement Day. 
Another instance will serve to prove that vocational and club work is constructive in Fountain County and has to do largely with the shaping of its ideals. Landscaping five years ago was almost an unheard-of thing in the county. The result of work done at the Veedersburg High School Building has reached numerous localities of the county. School yards are being landscaped and country churches are taking it up.

A very important undertaking along this line was the landscaping of the county court house yard at Covington. An appeal for aid to the county commissioners was made in 1921 thru the County Agent's office. Aid was given and the planting has been done.

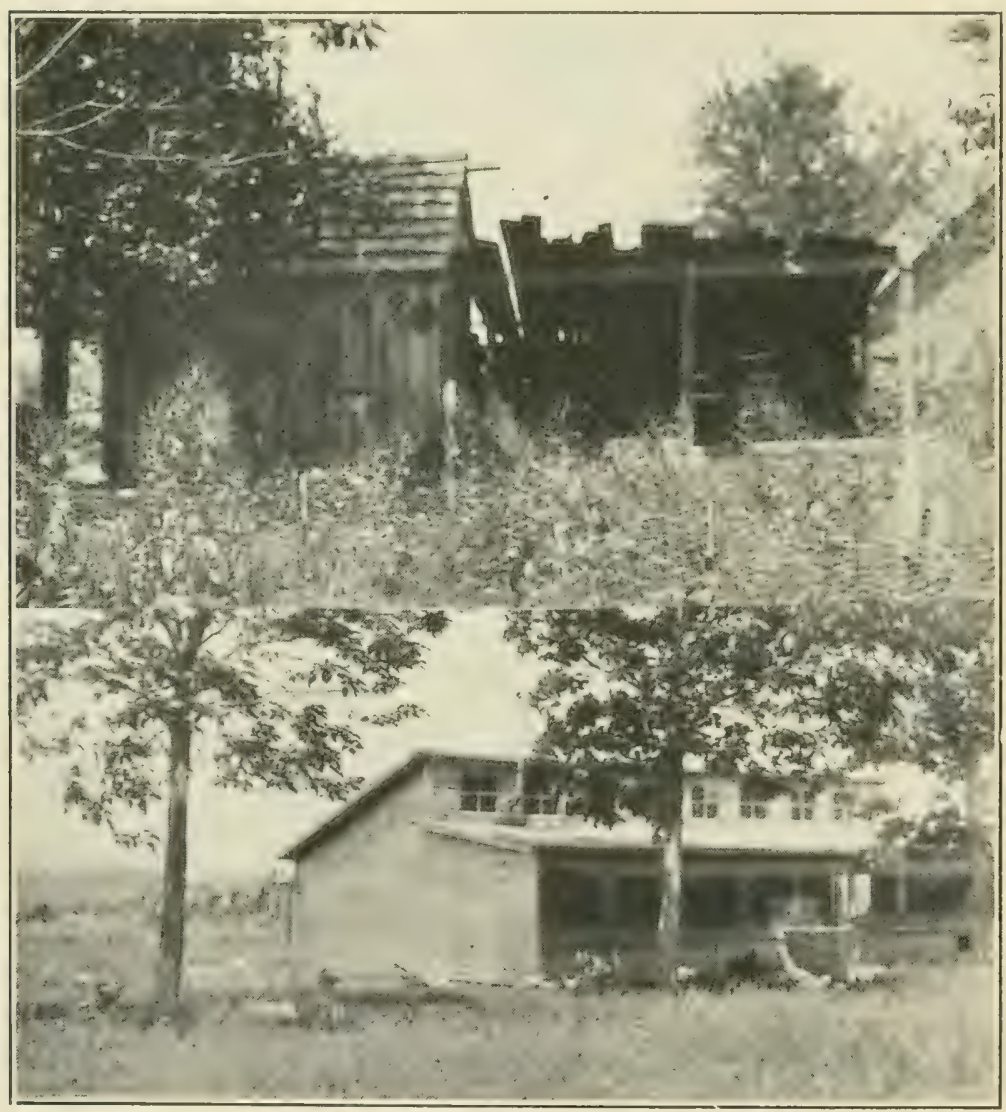

Gardner Crane's poultry house at the beginning of his poultry project, and the house built after a year's experience in poultry project work. 
A more recent development is the interest of the club folks in the new state highway. An effort is being made to secure and maintain a beautiful highway. Negotiations are now under way to obtain uniform fencing throughout the county along this highway.

Surely the results club work has brought about, and will in the future bring about, will at least make Fountain County a better place in which to live."

WILLIAM WRIGHT, Hillsboro.

\section{Excerpts from Statements Concerning the Vocational and Club Work in Fountain County}

"The teaching of vocational subjects in local high schools over Fountain County has been going forward with increased interest. A survey which was made recently disclosed the fact that over $50 \%$ of the pupils are from the country and that more than $77 \%$ of the pupils in a ten-year period have returned to the home community to reside. The fact that $50 \%$ of all pupils who graduate from high school return to their home community, to say nothing of the mass of young people who do not enter high school from that community, is evidence that vocational education has a place in Fountain County and should share equally with academic subjects in preparing boys and girls for the thing they will eventually do. Veedersburg is meeting the vocational problems in a fine way. Twenty-nine per cent of the Veedersburg high pupils are enrolled in vocational courses.

Comparing the Veedersburg community with a neighboring township we find that in the former where consolidated schools, vocational education and club work are strongly supported the tax rate is not as high as in the latter where oneroom schools are maintained and no vocational work is done.

The club work more than pays the cost of its maintenance. For the year 1921 there were 511 club member's that completed their projects and made reports. These boys and girls produced $\$ 22,900$ worth of products at a profit of $\$ 9,017.00$. The amount paid for county and township club supervision was $\$ 4,208.00$, leaving a net balance to the county of $\$ 4,808.00$.

Club and vocational work and consolidated schools are proving to be the solution of the farm and home problems in Fountain County. Through these excellent practical means 
the right attitude toward agriculture as a basic industry is being created, and rural leadership is being developed. In Van Buren Township, which maintains consolidated schools and a strong program in club and vocational work, $47 \%$ of all pupils graduated from high school in the last five years have gone to college to prepare in a better way for rural life, as compared with $15 \%$ in the township with one-room schools and a meager club program."

A. J. Hesler, County Club Leader.

"Agriculture and home economics in the schools have revolutionized the school into a vital community social institution in which all professions have been interested. The society of which our boys and girls are members is a democracy that must have leaders which it continually develops. One illustration of the democratic character of club work is the annual club picnic. It has attracted the attention of all classes of people, who come together in one common interest. The many hundreds mingled together each year creates a bond of fellowship and a sympathetic understanding which will make for proper relations in the future.

Agricultural education in Fountain County is to have a prominent place in the future considering the fact that over 2,000 boys and girls have taken part in club activities in the last five year's. Tho many of them have not gained prominence, yet these boys and girls make up the masses who will in the days to come determine the policy of rural education and community development."

WM. Madigan, Farmer and Banker.

"Club work by our boys and girls is fundamental to successful farming and home-making. Fountain County boys and girls are securing training and experience through club and vocational work that will make them successful as tenant farmers, and as farm owners. The project work is an important part of the school program in agriculture and home economics."

VERNON BABB, Tenant Farmer. 
"Our township is very enthusiastic over the club and vocational work our children are doing. Our vocational work is under the direction of Mr. Foster D. Poe, an enthusiastic, hard working, conscientious Purdue alumnus. He is training our boys to be lover's of the land instead of lover's of the city."

W. E. BRANT, Township Trustee.

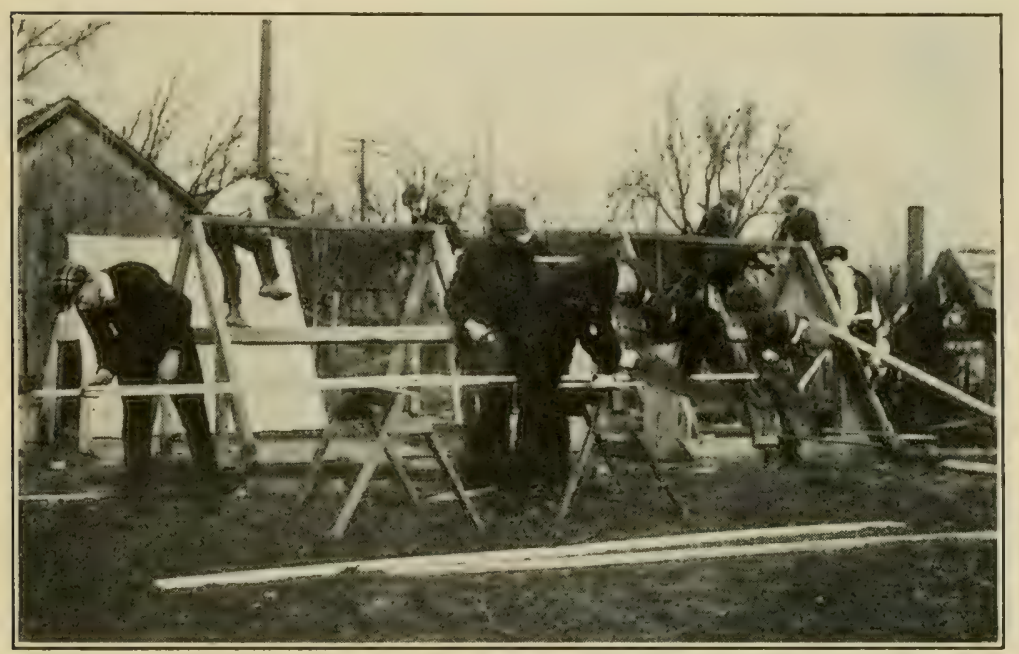

Vocational and club boys building houses for use in swine project work.

"Mrs. Smith and I consider the greatest asset we have been blessed with is our boys and girls. We do not try to teach our' children that education is a preparation for life, but rather that education is life itself. Therefore, we believe in and welcome boys' and girls' club work, and hope it will continue to grow in our county."

\section{ROY E. SMITH.}

"There is nothing that is doing more toward the building of a sound and stable agriculture in our county than boys' and girls' club work. The plan and its execution have been highly satisfactory. Our organization has the heartiest encouragement and recommendations for the work being done in the boys' and girls' clubs."

McM. CofFing, Secretary-Treasurer County Farm Bureau. 
There were 1,000 girls' club exhibits in sewing, baking and canning at the county fair in 1921. These exhibits occupied two-thirds of the space in the Arts Building.

The pictures on these two pages tell the story of the rapid increase in the number of club livestock exhibits at the county fair.

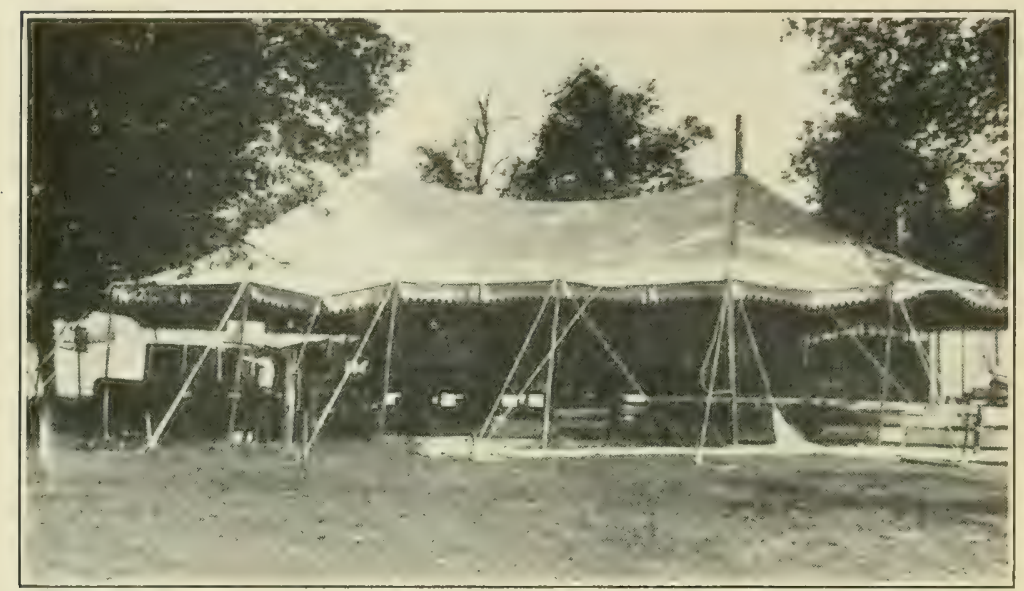

This tent housed the first boys' and rirls' club exhibits of livestock at the Fountain County Fair.

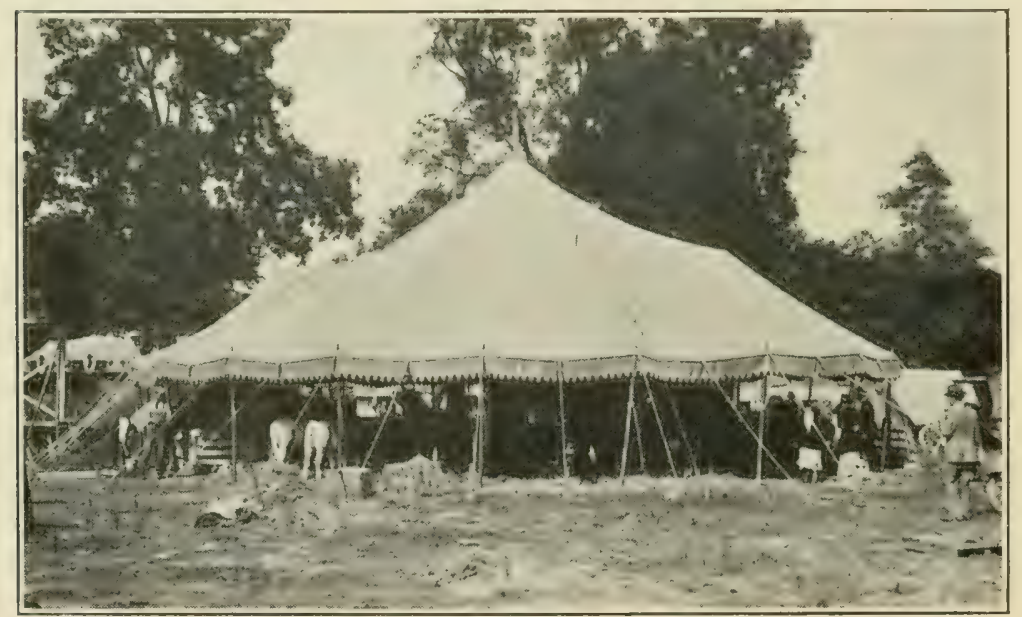

The second year the club livestock cxhibits at the County Fair required a tent bi) feet by 100 feet. 


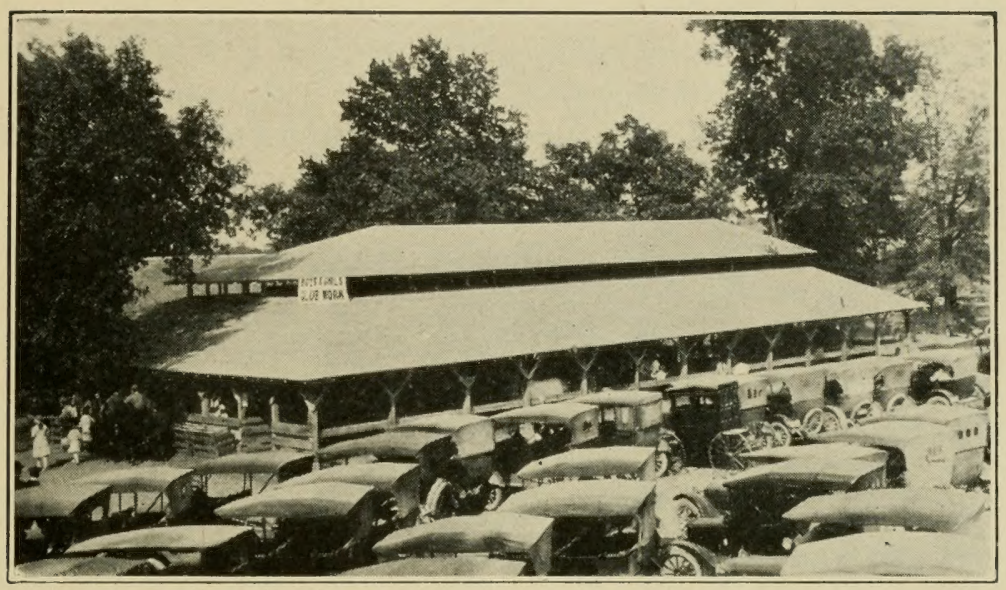

This pavilion 60 feet by 100 feet was constructed by the county fair board to take the place of the tent used for club livestock exhibits.

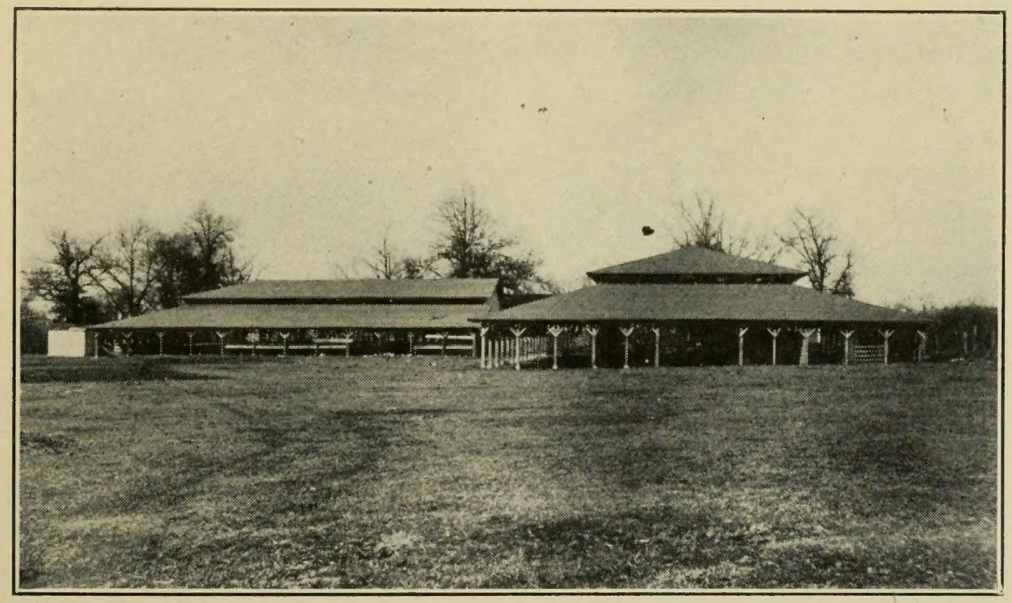

The club livestock exhibits at the county fair increased from year to year until a second pavilion the size of the first was required. 
"I have observed the results of club work in our county. In one instance the county leader influenced two boys to enter the Shorthorn heifer club, and under his guidance they have developed the foundation stock for a good herd of cattle. These boys expect to continue their club work and in this way make enough money to finance themselves through college. This is just one sample of the splendid work that is being accomplished through club work in our county."

\section{H. K. BilsLand,}

President County Shorthorn Breeders Assn.

"In years to come the real worth of club work will be shown in the efficiency of men and women who received training through this work in our county."

\section{WARREN H. RANDOLPH.}

"The value of the club work the boys and girls of our county are doing can not be measured in dollars and cents. While as a rule club work shows a profit from the financial side, yet its greatest value is in teaching the boy or girl to see. To be able to know when to do a thing and how to do it is one of the greatest blessings of a boy or girl.

Club work promotes the social and moral welfare of the child. It promotes good fellowship and cultivates the desire to possess that which is best, be it a calf, pig, canned goods or an apron. The desire for good things is not only created in

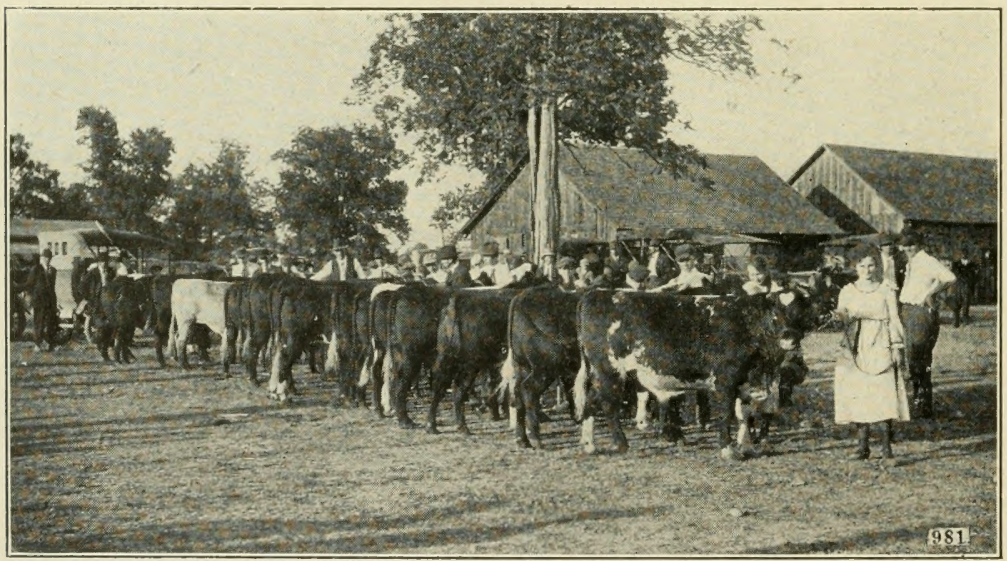

One group of baby beeves exhibited at the Fountain County Fair by vocational and club boys and girls. 
the club member but it is extended to the mother and father and to the community at large."

\section{M. FLOREY.}

"The club work being done by our boys and girls is to my mind the best means yet employed to dignify labor and make better home-makers of the present and coming generations."

VIOLA G. BAKER, Editor Veedersburg News.

"In my opinion it is impossible to gauge in dollars and cents the value of the boys' and girls' club work in Fountain County. One can not place a dollar mark on an ideal. If one puts up against the cost of our club work the ideals of the boys to raise better livestock and to feed it more economically, to plan the farms they will sometime own and to adopt thereon a system of crop rotation, and the ideals of the girls to make better homes, then the credit side of the ledger will show a most amazing balance in its favor."

A. H. LINDLEY, State Senator. 


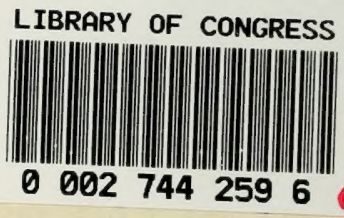

